Copyright (C) 2017 by Academic Publishing House Researcher

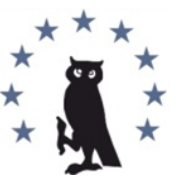

Published in the Russian Federation

European Researcher. Series A

Has been issued since 2010.

ISSN 2219-8229

E-ISSN 2224-0136

2017, 8(4): 329-338

DOI: $10.13187 /$ er.2017.4.329

www.erjournal.ru

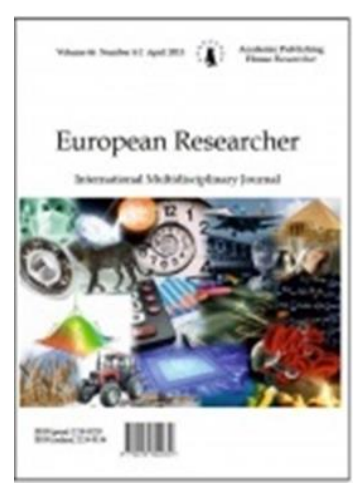

UDC 698

\title{
Management Analysis of Construction Acceleration of Library Building
}

\author{
Rizal Zaini a , *, Sutanto Hidayat a, Andrianus Agus Santosa a \\ a National Institute of Technology Malang, East Java, Indonesia
}

\begin{abstract}
In project planning, the process of determining optimum duration is an important step. This research was conducted on library building project of State Islamic Institute of Samarinda. The construction of this building demands acceleration due to the urgency of need, after experiencing 9 days delay on bore pile work. This study aimed to analyze the duration of required time acceleration by fast track work performance and analyze the total cost of the project after the fast track. This research was done by arranging material from related books and field survey results. The method of problem solving was Fast Track method. Based on the research results, it was known that the use of fast track method in the construction work of State Islamic Institute of Samarinda's library building can save time as much as 9 working days from the total normal day of 60 working days or about $15 \%$ of the implementation time. Implementation of fast track method to accelerate the construction of State Islamic Institute of Samarinda's library building had enabled savings of Rp.27.300.000,00 from the total cost of the physical work implementation as much as Rp. 5.458.455.157,30. This amount is equal to $0.50 \%$ of the overall cost. This acceleration of work did not increase the cost of physical work, and even can save indirect costs. However, to maximize the implementation of fast track method in the field, it required good management and qualified workers, as well as optimal control of the work implementation.
\end{abstract}

Keywords: Construction Management, Construction Acceleration, Project, Fast Track.

\section{Introduction}

Project is a set of interconnected activities that has starting points and endpoints and specific outcomes; project is usually cross-organizational function; it requires various skills from different professions and organizations (Whelton, 2004). Each project is unique, and even there are no two projects are exactly the same. A project is an effort that mobilizes the available resources, and is organized to achieve certain important goals, objectives and expectations and must be completed within a limited time based on the agreement (Dipohusodo, 1995; Loosemore et al., 2003). Project can be defined as a series of activities that occurs only once, where the implementation is limited by a certain period of time from the beginning to the end (Swink, 2003). Project activities can be interpreted as a temporary activity that occurs for a limited time, with specific resource allocations and is intended to produce products or deliverables whose quality criteria are clearly outlined.

\footnotetext{
${ }^{*}$ Corresponding author

E-mail addresses: rizal282828@gmail.com (Rizal Zaini)
} 
Project is a part of the work program of an organization that is temporary to support the achievement of organizational goals, by utilizing human and non-human resources (Munawaroh, 2003).

Project duration is the amount of required time to complete the entire project work. Factors that affect the duration of the project are the volume of work, construction method, the condition of the field, and the skills of the workers who carry out the construction project (Olander, Landin, 2005). Generally, when project duration increases in length, the cost of implementation will increase, and vice versa. It is caused by the overhead costs which the amount is depending on the duration of the implementation. There are several factors that determine the length of an activity, such as: 1) Activities with larger volumes require longer completion times compared to smaller work volumes, 2) skilled, educated and experienced workers will have high productivity so that they can complete the work quickly and in good quality, 3) weather factor plays an important role in the field implementation. If the weather is bad, it will disrupt the implementation of work, 4) project location, and 5) time estimation procedure.

The first step in determining the optimum duration for a project is to prepare a network schedule and estimate for the project. Schedule and estimate explain the project's normal cost. Normal cost is determined by estimate, and is tracked from the activities. This cost explains the direct cost of the project; combining direct costs with indirect costs that is generated from the total cost for the project. If a network contains one critical track then only one activity should be shortened. And if there is more than one critical track, then more than one activity will be crashed.

Although it is clearly advantageous to optimize the project duration on a cost basis, it is not a routine step in project planning. The unification of schedule and estimate information cannot be easily connected since the activity units are not the same. And it is not common to calculate the cost of crash for each activity then analyze and compare the cost of crashes with indirect costs. The problem is when a project is crashed, some critical tracks are formed, and when more critical paths appear, the greater risk of delays occurs in project completion (Oberlender, 1993).

The process of determining the optimum duration for a project is an important step in project planning. Time adjustments and money can be saved with a good cost analysis of the project then run the project at the most effective cost (Thomas, 2000). If we are attempting to reduce the expected fastest time for a project in which activities are part of its critical track, we first accelerate activities whose activity time can be reduced at a not-too-costly cost, otherwise the reduction of the normal time of costly activities will be undertaken if all other activities that have more profitable costs have been accelerated (Gerk, Qassim, 2008). In accelerating an activity, the first thing to do is to know which activities should be accelerated so that the overall completion time will be faster. Therefore, the step that needs to be conducted is to accelerate the activities that can change the final completion time so that the costs incurred are not as high as if all activities are accelerated.

State Islamic Institute of Samarinda, formerly known as State Islamic High School (STATE ISLAMIC INSTITUTE OF SAMARINDA) Sultan Sulaiman is one of the State Islamic Institute in Samarinda. This campus was established based on Presidential Decree No. 11 dated March 21, 1997 to coincide with Date 12 Dzulqaidah 1417H. IAIN Samarinda vision is "being an excellence and leadership Islamic universities in the development of Islamic civilization through education, research and community service in Borneo in 2025". Vision is very important as a lifeline for the entire academic in achieving the goals of the institution. Vision as the mainstay to run its activities to be more systematically, consistently and balanced so that the achievement of a strategic plan that has been set can easily be measured.

Mission of IAIN Samarinda. The missions of State Islamic High School of Samarinda (State Islamic Institute of Samarinda) are as follow: developing Islamic science, art and culture which are relevant to the development and the needs of the community, building a strong and deeply rooted academic tradition, producing graduates who have professional competence, skills and attitudes, educating students to think and be critically and creatively, educating students to have stability and moral virtue, educating students to be able to actualize the Islamic values in the practical life of society, nation and state, having an active role in community development, in East Kalimantan region especially, through education, research and community service.

Library of the State Islamic Institute of Samarinda is one type of library of Universities that participate in implementing Tridarma Perguruan Tinggi in the field of library. In the Indonesian 
Constitutions No.02 of 1989 on the National Education System mentioned that the library is a very important source of learning, although it is not the only one. As a center of learning and information resources and knowledge, the library of the State Islamic Institute of Samarinda is also an institution that occupies a very strategic, economic and democratic position as an effort to contribute to the intellectual life of the nation, as being aspired in the opening of the 1945 Constitution, to play its role in the implementation of self-study, lifelong learning for individuals or community groups, especially for students.

In an effort to realize these ideals, the technical staff section of the State Islamic Institute of Samarinda library, needs to calculate the implementation schedule to consider the targets to be achieved, therefore there must be knowledge of the methods that can be more efficiency in the implementation time and cost. The college library can serve as a source of information and as a source of learning, and one of the main indicators to realize the vision and mission of the State Islamic Institute of Samarinda and to establish the Post-Graduate program. It usually happens when the library has a large collection of library materials that meet the needs of students and lecturers, professional arrangement, facilities and infrastructure that are sufficient for the future library standards.

Seeing the very urgent need for the construction of the library building at the State Islamic Institute of Samarinda, the acceleration of construction is conducted. The analysis of construction acceleration management of IAIN Samarinda library building is implemented by accelerating the duration of the project although it will be followed by incurring more costs. At that time, there was a delay on the work of the bore pile where the start schedule had been delayed for 9 days and the deviation was minus. Due to the delay, acceleration of time was made during the implementation, minimum of 9 days for the work of the structure of the library building, with Fast Track method.

Based on the background above, then the research problems that can be taken from this research are: 1) how much time acceleration duration of fast track work implementation is, 2) what is the total cost of project after the implementation of fast track. Based on the research problems, the objectives of this research are: 1) to analyze the amount of acceleration duration / time required after the implementation of fast track method, 2) to analyze the total cost of the project after the implementation of fast track method.

\section{Research Methods}

The compilation of the article requires steps that are structured and systematic, it is called research methodology, so that it is expected to solve existing problems, scientifically, detailed and accountable. The method in writing this article is by arranging materials from related books and from materials obtained from the lectures and from field surveys. This method is structured with the following steps:

a. Identify problems that occur in the project: the delay in the implementation of the project, which means that it exceeds the predetermined time limit which can lead to a larger project cost budget.

b. To solve the problems that have been formulated, then the right and correct basic theory is needed. Literature related to the network work is searched through the literature study.

c. Finding and collecting the required data, such as the project implementation schedule and cost budget plan. The data are obtained from the implementing contractor.

d. Analyzing the obtained data and resolve formulated problems.

This research uses Fast Track method as a problem solving. The problem here is the difference in the age of the project to the age of the project plan that has been established (Bogus et al., 2003). The age of project plan is usually shorter than the age of the project implementation. The election in recovering the project's progress rate is to speed up the duration of the project even though it will add more costs. One way to speed up the duration of the project, it is crashing. The terminology of crashing process is to reduce the duration of a work that will affect the project completion time. Crashing process is centered on activities that are on the critical track.

Acceleration duration can be conducted on activities that are traversed by the critical track. There are several ways to speed up an activity, in order to get the best alternative based on the conditions of the implementing contractor (Pena-Mora, Li, 2001). These are the ways, for example:

a. Changes in the logic of interdependence between activities

b. Addition in the human resources 
c. Carrying out overtime work

d. Addition or replacement in the equipment

The preceding things will certainly increase the cost. The addition of these costs will provide a massive difference in cost due to the acceleration time based on the amount of the acceleration time (Kasim et al., 2005). Analysis technique used in this research is Fast Track method. Estimated time of completion of a project can be determined by: Single duration estimate for every activity (CPM approach) (Demeulemeester, Herroelen, 2006). The steps / conditions that must be conducted in the implementation of fast track method, to the activities on the critical track, are as follow: Scheduling must be logical between one activity and another so it is realistic to be implemented (including: the labor, productivity, materials, tools, technical, and funds). Performing fast-tracks is only on activities on critical tracks, especially on activities that have a long duration.

\section{Results and Discussion}

\subsection{Identifying Works}

In this research, work items to be studied are the structured work with job details such as shown in Table 1.

Table 1. Work Item

\begin{tabular}{|c|c|c|}
\hline No & Job Description & Information \\
\hline \multirow{4}{*}{1} & First Floor Structure Works & \\
\hline & Tie Beam & \\
\hline & Column & \\
\hline & Stairs & \\
\hline \multirow{5}{*}{2} & Second Floor Structure Work & \\
\hline & Beam & \\
\hline & Floor Plates & \\
\hline & Column & \\
\hline & Stairs & \\
\hline \multirow{5}{*}{3} & Third Floor Structure Work & \\
\hline & Beam & \\
\hline & Floor Plates & \\
\hline & Column & \\
\hline & Stairs & \\
\hline \multirow{4}{*}{4} & First Roof Floor Structure Work & \\
\hline & Beam & \\
\hline & Floor Plates & \\
\hline & Column & \\
\hline \multirow{3}{*}{5} & Second Roof Floor Structure Work & \\
\hline & Beam & \\
\hline & Floor Plates & \\
\hline
\end{tabular}

\subsection{Identifying the Project Cost}

3.2.1 Project Direct Cost

Project Direct Costs are costs that are directly related to the volume of work that is listed in the employment contract that changes when the volume of work changes. This cost consists of the cost of the worker performing the work and the cost of materials used for the work such as sand, reinforcing steel, cement, bricks and so on. The direct costs of the construction of library building of State Islamic Institute of Samarinda are presented in Table 2. 
Table 2. Recapitulation of Direct Costs in the Normal Time

\begin{tabular}{|l|l|r|l|}
\hline No & Job Description & Total Material Cost (IDR) & Total (IDR) \\
\hline 1 & First Floor Structure Work & $643.288 .606,67$ & \multirow{1}{*}{} \\
\cline { 1 - 3 } 2 & Second Floor Structure Work & $1.300 .371 .660,36$ & \multirow{2}{*}{$4.155 .988 .225,50$} \\
\hline 3 & Third Floor Structure Work & $1.249 .506 .337,56$ & \\
\cline { 1 - 2 } 4 & First Roof Floor Structure Work & $895.858 .153,44$ & \\
\hline 5 & Second Roof Floor Structure Work & $66.973 .467,77$ & \\
\hline 6 & Total Wage Fees & $1.120 .456 .931,80$ & $1.120 .456 .931,80$ \\
\hline & Total number & & $5.276 .455 .157,30$ \\
\hline
\end{tabular}

\subsubsection{Indirect Costs}

Indirect costs are not fixed costs that may change over required time for the job and are not directly related to the volume of work in the field. Examples of indirect costs are office rent, personnel salary, project security costs, electricity and water for the work. Indirect costs are usually not mentioned in the volume of work on physical work contracts. The indirect cost of construction the library building of the State Islamic Institute of Samarinda is presented in Table 3.

Table 3. Indirect Costs

\begin{tabular}{|l|l|l|l|r|r|}
\hline No & Description & Volume & Month & Salary Per Month (IDR) & Total Salary (Rp) \\
\hline 1 & Staff Salary Costs & & & & \\
\hline & Project Manager & 1 & 1 & $15.000 .000,-$ & $15.000 .000,-$ \\
\hline & Site Structure Manager & 1 & 1 & $10.000 .000,-$ & $10.000 .000,-$ \\
\hline & Executor of K3 & 1 & 1 & $5.000 .000,-$ & $5.000 .000,-$ \\
\hline & Drafter & 2 & 1 & $3.500 .000,-$ & $7.000 .000,-$ \\
\hline & Executing Structure & 1 & 1 & $3.500 .000,-$ & $3.500 .000,-$ \\
\hline & Logistics & 1 & 1 & $2.000 .000,-$ & $2.000 .000,-$ \\
\hline & Surveyor & 1 & 1 & $2.500 .000,-$ & $2.500 .000,-$ \\
\hline & Assistant Surveyor & 1 & 1 & $2.000 .000,-$ & $2.000 .000,-$ \\
\hline & Office Boy/General Section & 1 & 1 & $1.500 .000,-$ & $1.500 .000,-$ \\
\hline & Night Guard & 2 & 1 & & $3.000 .000,-$ \\
\hline 2 & Facilities/Equipment Costs & & & & \\
\hline & Telephone & 2 & 1 & $1.500 .000,-$ & $3.000 .000,-$ \\
\hline & Hiring Generator set & 1 & 1 & $9.500 .000,-$ & $6.500 .000,-$ \\
\hline & Diesel Fuel & 3000 & 1 & $1.000 .000,-$ & $27.000 .000,-$ \\
\hline & Water & 1 & 1 & $500.000,-$ & $2.000 .000,-$ \\
\hline & Cost of Field Meeting & 4 & 1 & & $91.000 .000,-$ \\
\hline & Indirect Cost for 1 Month & & & & $3.033 .333,-$ \\
\hline & Indirect Cost per 1 Day & & & & \\
\hline
\end{tabular}

\subsection{Schedule of Work Performance Normal Time}

Items, whose fast track implementation are examined on the construction of a library building at the State Islamic Institute of Samarinda is only on the structural works. Normal time job schedule is obtained from the contractor. But the schedule for the implementation of this work is not made in detail and it only mentions the time for the structural work for 60 calendar days. The work starts from the stairs of May 2, 2016 to 60 days ahead. The data are obtained in the form of the S Curve. The detail schedule of the implementation of the work can be seen in the appendix. In this library construction, the building owner requests the construction to be accelerated for the inauguration that will be conducted by the Minister of Religion who will inaugurate before the time of the contract is expired so that it is requiring a method of acceleration of work that is effectively and efficient and does not require big cost in its implementation. 
Implementation schedule is made in detail with help of Excel 2016 program and can be seen in the appendix. To perform the acceleration of work with the Fast Track method, it firstly needs to know the critical track on the job. To determine the critical track of the work, Diagram Critical Patch Method is used; it is an activity-on-arrow network of logically arranged activities with the finish-to-start relationship that can show the activities through which the track is critical. In determining the schedule of activities, firstly it must be known the amount of resources owned and productivity of each existing resources for the appropriate work. For the making of network diagram the main job is taken on this work. In the budget plan, the cost of work items is made in detail and based on several different elements of the beam and columns. To simplify the creation of Network Diagrams, work items are made into several main groups and separated by structure components. For example, the column structure component consisting of multiple columns is combined into 1 column item. Beams, consisting of several types of beams, are combined into one beam item. The duration of the activity is the required time to complete the job. This can be seen in Table 4.

Table 4. Calculation of Duration of Work

\begin{tabular}{|c|c|c|c|c|c|}
\hline No. & Job Description & $\begin{array}{l}\text { Number of } \\
\text { Activities }\end{array}$ & $\begin{array}{l}\text { Previous } \\
\text { Activity }\end{array}$ & Order & $\begin{array}{l}\text { Normal } \\
\text { Duration } \\
\text { (days) }\end{array}$ \\
\hline \multirow[t]{4}{*}{1} & First Floor Structure Work & & & & \\
\hline & Tie Beam & $\mathrm{A}$ & $\mathrm{A}$ & 1 & 5 \\
\hline & Column & $\mathrm{B}$ & $\mathrm{D}, \mathrm{E}$ & 2 & 6 \\
\hline & Stairs & $\mathrm{C}$ & $\mathrm{D}$ & 14 & 10 \\
\hline \multirow[t]{5}{*}{2} & Second Floor Structure Work & & & & \\
\hline & Beam & $\mathrm{D}$ & $\mathrm{B}$ & 3 & 9 \\
\hline & Floor Plates & $\mathrm{E}$ & $\mathrm{B}$ & 4 & 9 \\
\hline & Column & $\mathrm{F}$ & $\mathrm{D}, \mathrm{E}$ & 5 & 6 \\
\hline & Stairs & $\mathrm{G}$ & $\mathrm{H}, \mathrm{I}$ & 15 & 10 \\
\hline \multirow[t]{5}{*}{3} & Third Floor Structure Work & & & & \\
\hline & Beam & $\mathrm{H}$ & $\mathrm{F}$ & 6 & 9 \\
\hline & Floor Plates & I. & $\mathrm{F}$ & 7 & 9 \\
\hline & Column & $\mathrm{J}$ & $\mathrm{H}, \mathrm{I}$ & 8 & 6 \\
\hline & Stairs & $\mathrm{K}$ & $\mathrm{L}, \mathrm{M}$ & 16 & 6 \\
\hline \multirow[t]{4}{*}{4} & First Roof Floor Structure Work & & & & \\
\hline & Beam & $\mathrm{L}$ & $\mathrm{J}$ & 9 & 9 \\
\hline & Floor Plates & $\mathrm{M}$ & $\mathrm{J}$ & 9 & 9 \\
\hline & Column & $\mathrm{N}$ & $\mathrm{L}, \mathrm{M}$ & 6 & 6 \\
\hline \multirow[t]{3}{*}{5} & Second Roof Floor Structure Work & & & & \\
\hline & Beam & $\mathrm{O}$ & $\mathrm{N}$ & 12 & 5 \\
\hline & Floor Plates & $\mathrm{P}$ & $\mathrm{N}$ & 13 & 5 \\
\hline
\end{tabular}

After knowing the implemented duration of the work, it can be made a network diagram as shown in Figure 1. 


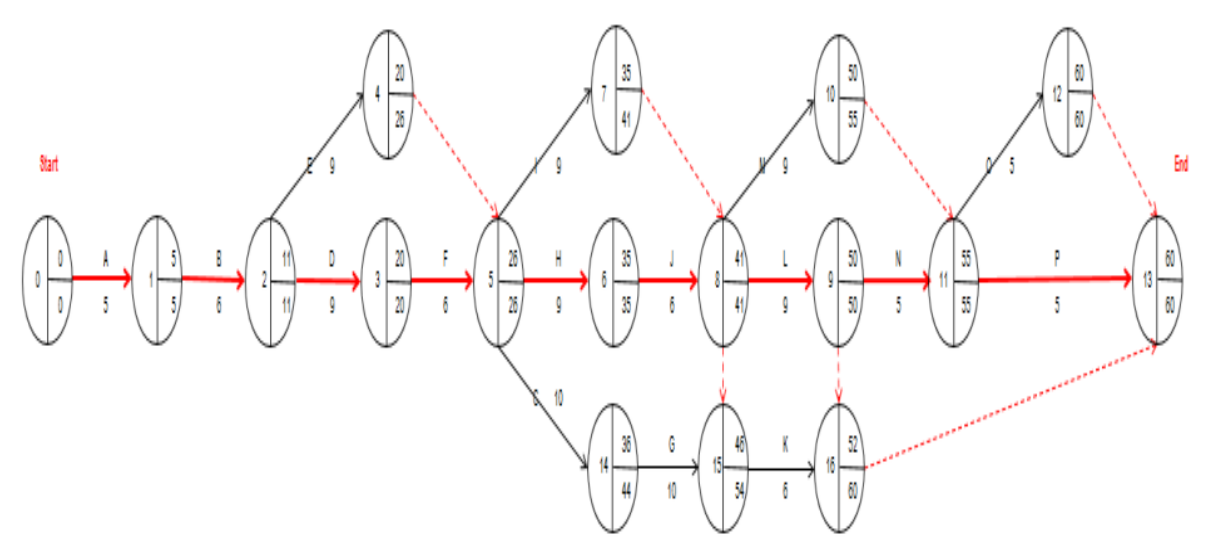

Fig. 1. Network Diagram of Normal Time

From the calculation and making of the network diagram, it is found that the normal time in the implementation of the work of this structure is 60 calendar days. From the data network diagram above, the critical track is a thick red line, which is the track on the work with the code of activities A, B, D, F, H, J, L, N and P.

\subsection{Fast Track}

Fast track method is a method of acceleration that is conducted in a work so that the time of completion of work faster than the normal time. In this fast track method, work is conducted overlapping or conducted in parallel between one job and the other. The provisions used for the application of the fast track method on the critical track are as follows (Tjaturono, 2006).

a. Scheduling must be logical between one activity and another activity so that it is realistic enough to be implemented (including labor, productivity, materials, tools, money and funds).

b. Doing fast tracks only for activities on the critical track, especially on activities that have a long duration.

c. Shortest time that can be conducted by fast track is $\geq 2$ days

d. The relationship between the critical activities that will be on the fast track is:

e. If the duration of $\mathrm{i}$ (initial activity) is less than duration $\mathrm{j}$ (next activity) then critical activity $\mathrm{j}$ can be conducted after the duration of activity $i$ has finished $\geq 1$ day or one time unit and activity $i$ must be finished first or together. If the duration of $i$ is greater than the duration of $j$, then activity $j$ can begin when the duration of activity $i<1$ day from the duration of activity $j$.

f. Check the existing float on the activities that are not critical, whether they are still eligible and uncritical after the fast track is conducted or not.

g. If the critical path is shifted after conducting the fast track at the initial stage, the same step is taken to the activity on the new critical track.

h. Time acceleration should be done no more than $50 \%$ of normal time.

i. After paying attention to the above provisions, it also needs some things to support the achievement of acceleration in the field, including:

j. Good management skills

k. Good coordination between teams

l. Focus on the critical track

m. Good control

To speed up the work in the field, fast track is conducted on the following critical track as seen in Table 5 . 
Table 5. Calculation of Acceleration Duration of Work

\begin{tabular}{|c|c|c|c|c|c|c|}
\hline No. & Job Description & $\begin{array}{l}\text { Number of } \\
\text { Activities }\end{array}$ & $\begin{array}{l}\text { Previous } \\
\text { Activity }\end{array}$ & $\begin{array}{l}\text { Normal } \\
\text { Duration } \\
\text { (days) }\end{array}$ & $\begin{array}{l}\text { Acceleration } \\
\text { (days) }\end{array}$ & $\begin{array}{l}\text { Duration of } \\
\text { Fast Track } \\
\text { (days) }\end{array}$ \\
\hline \multirow[t]{4}{*}{1} & $\begin{array}{l}\text { First Floor } \\
\text { Structure Work }\end{array}$ & & & & & \\
\hline & - $\quad$ Tie Beam & $\mathrm{A}$ & & 5 & 1 & 4 \\
\hline & - $\quad$ Column & $\mathrm{B}$ & $\mathrm{A}$ & 6 & 1 & 5 \\
\hline & - $\quad$ Stairs & $\mathrm{C}$ & $\mathrm{D}, \mathrm{E}$ & 10 & & 10 \\
\hline \multirow[t]{5}{*}{2} & $\begin{array}{l}\text { Second Floor } \\
\text { Structure Work }\end{array}$ & & & & & \\
\hline & - $\quad$ Beam & $\mathrm{D}$ & $\mathrm{B}$ & 9 & 1 & 8 \\
\hline & $\begin{array}{ll}\text { - } & \text { Floor Plates }\end{array}$ & $\mathrm{E}$ & $\mathrm{B}$ & 9 & 1 & 8 \\
\hline & - Column & $\mathrm{F}$ & $\mathrm{D}, \mathrm{E}$ & 6 & 1 & 5 \\
\hline & - $\quad$ Stairs & $\mathrm{G}$ & $\mathrm{H}, \mathrm{I}$ & 10 & & 10 \\
\hline \multirow[t]{5}{*}{3} & $\begin{array}{l}\text { Third Floor } \\
\text { Structure Work }\end{array}$ & & & & & \\
\hline & - $\quad$ Beam & $\mathrm{H}$ & $\mathrm{F}$ & 9 & 1 & 8 \\
\hline & $\begin{array}{ll}\text { - } & \text { Floor Plates }\end{array}$ & I. & $\mathrm{F}$ & 9 & 1 & 8 \\
\hline & - Column & $\mathrm{J}$ & $\mathrm{H}, \mathrm{I}$ & 6 & 1 & 5 \\
\hline & - $\quad$ Stairs & $\mathrm{K}$ & $\mathrm{L}, \mathrm{M}$ & 6 & & 6 \\
\hline \multirow[t]{4}{*}{4} & $\begin{array}{l}\text { First Roof Floor } \\
\text { Structure Work }\end{array}$ & & & & & \\
\hline & - $\quad$ Beam & $\mathrm{L}$ & $\mathrm{J}$ & 9 & 2 & 7 \\
\hline & - $\quad$ Floor Plates & $\mathrm{M}$ & $\mathrm{J}$ & 9 & 2 & 7 \\
\hline & - Column & $\mathrm{N}$ & $\mathrm{L}, \mathrm{M}$ & 6 & & 4 \\
\hline \multirow[t]{3}{*}{5} & $\begin{array}{l}\text { Second Roof Floor } \\
\text { Structure Work }\end{array}$ & & & & & \\
\hline & - $\quad$ Beam & $\mathrm{O}$ & $\mathrm{N}$ & 5 & & 5 \\
\hline & $\begin{array}{ll}- & \text { Floor Plates }\end{array}$ & $\mathrm{P}$ & $\mathrm{N}$ & 5 & & 5 \\
\hline
\end{tabular}

After knowing the implementation of fast for the implemented acceleration of work, then it can be used to make a network diagram as seen in Figure 2. From the results of acceleration with the fast track method, it is obtained the total length of work, it is 51 calendar days. Thus, the acceleration that can be conducted is for 9 days. After knowing the implementation of fast for the implemented acceleration of work, then it can be made the following network diagram. After knowing the implementation of fast for the implemented acceleration of work, then it can be made the following network diagram.

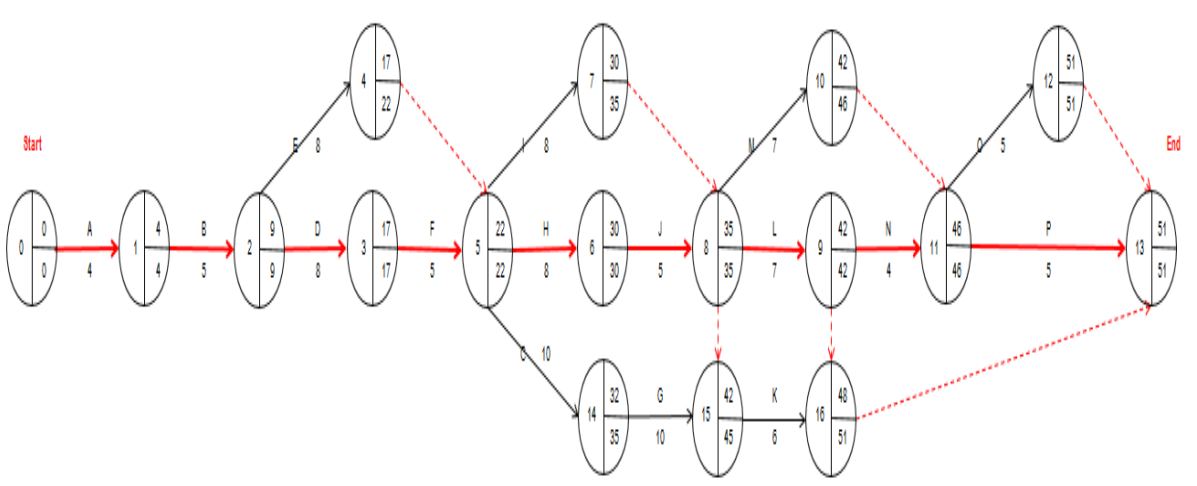

Fig. 2. Diagram Network of Acceleration Time 


\subsection{Cost Comparison After the Implementation of Fast Track Method}

Financing using fast track method, calculates the indirect cost as the calculation at normal time. For the calculation of direct costs there is no change to the amount of the available resources. Similarly, the use of fixed materials is calculated as calculation in normal time. However, in this research, it is assisted by using Excel Software 2016 so it can be calculated the labor hired per day, so it may calculate the real cost of the use of existing resources in this work. The cost difference occurs on indirect costs because the indirect costs are not directly related to the volume of work but relate to the length or duration of the work that can be saved in order to reduce the daily costs due to time reductions. The direct costs of the work are unchanged because there is no increase in the number of workers, so the amount of direct costs in normal time will be equal to the amount of direct costs of fast track time. This can be seen in Table 6 .

Table 6. Recapitulation Direct Cost After Fast Track Method

\begin{tabular}{|c|c|c|c|}
\hline No. & Job Description & Total Material Cost (IDR) & $\begin{array}{l}\text { Total } \\
\text { (IDR) }\end{array}$ \\
\hline 1 & First Floor Structure Works & $643.288 .606,67$ & \multirow[t]{5}{*}{$4.155 \cdot 988.225,50$} \\
\hline 2 & Second Floor Structure Work & $1.300 .371 .660,36$ & \\
\hline 3 & Third Floor Structure Work & $1.249 .506 .337,56$ & \\
\hline 4 & First Roof Floor Structure Work & $895.858 .153,44$ & \\
\hline 5 & Second Roof Floor Structure Work & $66.973 .467,77$ & \\
\hline \multirow[t]{2}{*}{6} & Total Wage Fees & $1.120 .456 .931,80$ & $1.120 .456 .931,80$ \\
\hline & Total Cost & & $5.276 .455 .157,30$ \\
\hline
\end{tabular}

Indirect cost savings are calculated by multiplying the number of days that can be treated efficiently with indirect daily costs. Indirect cost per working day is: IDR 3.033.333.33. The time that can be saved is 9 calendar days. Thus the cost that can be saved is 9 days $x$ IDR 3.033.333.33= IDR 27.300.000,-. Direct cost savings, total cost savings, and overall total cost of the normal time can be seen in Table 7, 8, and 9 respectively.

Table 7. Direct Cost Savings

\begin{tabular}{|l|l|c|c|}
\hline No & Job Description & Normal Time (IDR) & After Fast Track (IDR) \\
\hline 1 & Material & $4.155 \cdot 988.225,50$ & $4.155 \cdot 988.225,50$ \\
\hline 2 & Wages & $1.120 .456 .931,80$ & $1.120 .456 .931,80$ \\
\hline & Total & $5.276 .455 .157,30$ & $5.276 .455 .157,30$ \\
\hline & Savings & 0,00 \\
\hline
\end{tabular}

Table 8. Total Cost Savings

\begin{tabular}{llr}
\hline No & Job Description & Total Cost (IDR) \\
\hline 1 & Direct Cost & O,00 \\
2 & Indirect Costs & $27.300 .000,00$ \\
\hline & Total & $27.300 .000,00$ \\
\hline
\end{tabular}

Table 9. Overall Total Cost of the Normal Time

\begin{tabular}{|l|l|c|}
\hline No & Job Description & Total Cost (IDR) \\
\hline 1 & Direct cost & $5.276 .455 .157,30$ \\
\hline 2 & Indirect Cost of 6o days x IDR 3.033.333,33 & $182.000 .000,00$ \\
\hline & Total & $5.458 .455 .157,30$ \\
\hline
\end{tabular}




\subsection{Percentage of the Savings}

Percentage of the savings that can be achieved on the construction of the library is calculated by comparing the total savings with the overall total cost.

Total Savings $=($ IDR 27.300.000,00/IDR 5.458.455.157,30 $) \times 100 \%=0: 50 \%$

\section{Conclusion}

To be able to carry out the maximum results on the implementation of fast track method in the field at the acceleration of the construction of the library building of the State Islamic Institute of Samarinda, it is influenced by: good management skills and good workers, good team coordination, focus on work on critical track and the last one is a good control over the implementation of the work.

a. The use of fast track method performed on library construction of Samarinda Islamic Institute can save time as much as 9 working days of the total normal day as much as 60 weekdays, or about $15 \%$ of the implementation time.

b. The implementation of fast track method in the field, on the accelerated development of the Samarinda Islamic Institute library building, occurred savings of IDR 27.300.000, - of the total cost of the physical work implementation IDR 5.458.455.157,30. It is equivalent to $0.50 \%$ of the overall cost.

Acceleration made actually does not add to the cost of physical work, and even can save the indirect costs.

\section{References}

Bogus et al., 2003 - Bogus, S., Diekmann, J.E., Molenaar, K.R. (2003). A Methodology to Reconfigure the Design-Construction Interface for Fast-Track Projects. In Computing in Civil Engineering, 258-272.

Demeulemeester, Herroelen, 2006 - Demeulemeester, E.L., Herroelen, W.S. (2006). Project Scheduling: A Research Handbook Vol. 49. Springer Science \& Business Media.

Dipohusodo, 1995 - Dipohusodo. (1995). Manajemen Proyek \& Kontruksi. Jilid 2, Yogyakarta: Badan Penerbit Kanisius.

Gerk, Qassim, 2008 - Gerk, J.E.V., Qassim, R.Y. (2008). Project Acceleration via Activity Crashing, Overlapping, and Substitution. IEEE Transactions on engineering management, 55(4), 590-601.

Kasim et al., 2005 - Kasim, N.B., Anumba, C.J., Dainty, A.R.J. (2005). Improving Materials Management Practices on Fast-Track Construction Projects. In 21st Annual ARCOM Conference, SOAS, University of London. Vol. 2, 793-802.

Loosemore et al., 2003 - Loosemore, M., Dainty, A., Lingard, H. (2003). Human Resource Management in Construction Projects: Strategic and Operational Approaches. Taylor \& Francis.

Munawaroh, 2003 - Munawaroh. (2003). Principle of Management Construction. Semarang: Jendela Ilmu.

Oberlender, 1993 - Oberlender, G.D. (1993). Project Management for Engineering and Construction. Vol. 2. New York: McGraw-Hill.

Olander, Landin, 2005 - Olander, S., Landin, A. (2005). Evaluation of Stakeholder Influence in the Implementation of Construction Projects. International Journal of Project Management, 23(4), 321-328.

Pena-Mora, Li, 2001 - Pena-Mora, F., Li, M. (2001). Dynamic Planning and Control Methodology for Design/Build Fast-Track Construction Projects. Journal of Construction Engineering and Management, 127(1), 1-17.

Swink, 2003 - Swink, M. (2003). Completing Projects On-Time: How Project Acceleration Affects New Product Development. Journal of Engineering and Technology Management, 2o(4), 319-344.

Thomas, 2000 - Thomas, H.R. (2000). Schedule Acceleration, Work Flow, and Labor Productivity. Journal of Construction Engineering and Management, 126(4), 261-267.

Tjaturono, 2006 - Tjaturono. (2006). Manajemen Konstruksi. Bahan Kuliah Pascasarjana Magister Teknik ITN, Malang.

Whelton, 2004 - Whelton, M.G. (2004). The Development of Purpose in the Project Definition Phase of Construction Projects. Engineering-Civil \& Environmental Engineering. Berkeley, University of California, 313. 